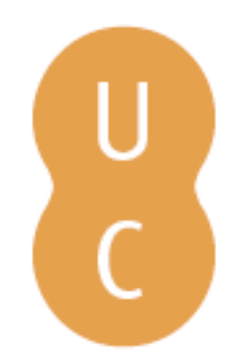

\title{
pommalina
}

\section{Neo-Darwinism and politico-ideological concepts in Portugal during the first half of the 20th century}

\author{
Autor(es): $\quad$ Nunes, João Paulo Avelãs \\ Publicado por: Imprensa da Universidade de Coimbra \\ URL \\ persistente: URI:http://hdl.handle.net/10316.2/31295 \\ DOI: $\quad$ DOI:http://dx.doi.org/10.14195/978-989-26-0342-1_20 \\ Accessed : $\quad$ 26-Apr-2023 14:14:56
}

A navegação consulta e descarregamento dos títulos inseridos nas Bibliotecas Digitais UC Digitalis, UC Pombalina e UC Impactum, pressupõem a aceitação plena e sem reservas dos Termos e Condições de Uso destas Bibliotecas Digitais, disponíveis em https://digitalis.uc.pt/pt-pt/termos.

Conforme exposto nos referidos Termos e Condições de Uso, o descarregamento de títulos de acesso restrito requer uma licença válida de autorização devendo o utilizador aceder ao(s) documento(s) a partir de um endereço de IP da instituição detentora da supramencionada licença.

Ao utilizador é apenas permitido o descarregamento para uso pessoal, pelo que o emprego do(s) título(s) descarregado(s) para outro fim, designadamente comercial, carece de autorização do respetivo autor ou editor da obra.

Na medida em que todas as obras da UC Digitalis se encontram protegidas pelo Código do Direito de Autor e Direitos Conexos e demais legislação aplicável, toda a cópia, parcial ou total, deste documento, nos casos em que é legalmente admitida, deverá conter ou fazer-se acompanhar por este aviso.

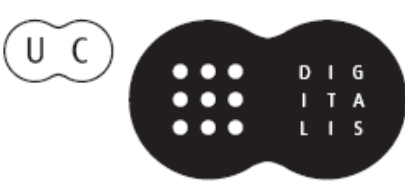


Ana Leonar Pereira João Rui Pita

Pedro Ricarda Fonseca (eds.)
Darwin,

Evalution,

Evolutionisms

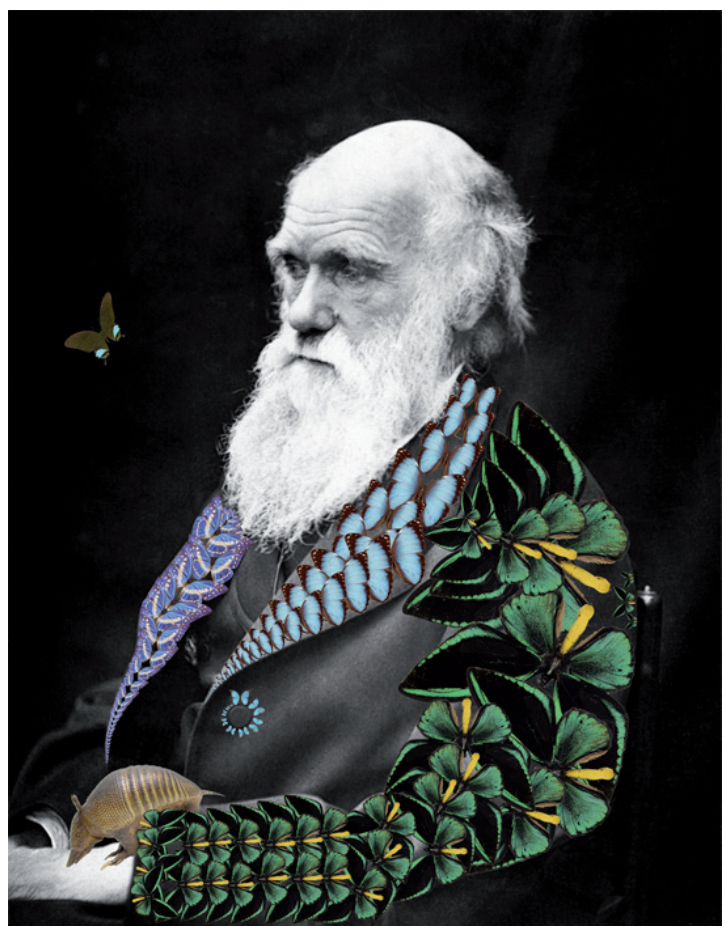




\section{Neo-Darwinism and politico-ideological concepts in Portugal DURING THE FIRST HALF OF THE $20^{\text {TH }}$ CENTURY}

The present paper is based on the assumption that world views that can generally be considered to be Neo-Darwinian or Socio-Darwinian play a central role in many dominant ideological trends in Western and Westernised countries, and that this was the case until at least the immediate aftermath of World War II. Except in the case of some Catholic sectors and most Socialist sub-universes, the tendency was to stratify peoples and individuals based on genetic and cultural criteria. The belief was that a countless number of behavioural attitudes and situations (both on an individual and on a collective level) resulted, directly or indirectly, from a certain set of "racial and environmental" characteristics.

The realisation of the great suffering caused by extreme cases of racism occurred just before the end of World War II and in the years immediately following the conflict. Before then, the hegemonic interpretation and assessment of "intrinsic characteristics" and the relative stratification of populations or nation states, groups of people and individuals, would have been "very radical or mildly radical" versions of Neo-Darwinian concepts. Some of the most telling examples of this outlook were the efforts made to physically eliminate European citizens of Jewish origin and other genocidal projects carried out by the National Socialist Third Reich, as well as the acts of mass violence inherent to Japanese militarist expansionism.

Thus, it could be said that social Darwinism played a core role in the transformation process of systemic ideological concepts (to a higher or lesser degree) into "truths demonstrated by science". As forms of scientism (whether they be rationalist or irrationalist), practically all the ideologies that were born in the 19th and 20th centuries strove to legitimise themselves through attributes that were supposedly scientific, according to the modern paradigm. These were: objectivity and truth, unquestionability and perennity, social prestige and the ability to intervene and transform.

In accordance with the context and with the needs of each one of the ideological trends (i.e. liberal conservative or autocratic, demoliberal, authoritarian or totalitarian), Neo-Darwinian readings took on different forms. Firstly, genetic - or racial - factors either played a crucial role or one that was only moderately relevant. On the other hand, the focus was either on the justification of profiles or individual behaviour (differentiation between "active citizens", "passive citizens" and "marginal" ones; members of the "elite", "intermediate segments" and "popular classes"), or on the explanation of the "operating mechanism" of human societies by analogy to "animal societies" (i.e. organic corporatism versus individualism and the "struggle for survival") 
and with the human body (i.e. intrinsic and benign values versus different, malignant or pathological sets of ideas from elsewhere).

As to the dimension of observed social phenomena, interpreted in the light of social Darwinism, the following were considered: national aspects (i.e. the relative positioning of men and women, employers or senior executives and workers, the "educated" and "uneducated", governors and the governed); colonial aspects (i.e. the guardianship of "primitive populations" by "civilized nations") and international aspects (i.e. the leadership of "superior races" and the "natural hegemony" of the more powerful states' interests). Even links "with the past" were conditioned by the wish to refer to or to highlight the founding moment of each "national race", to identify and emphasize stages of "genetic regeneration", and hide or deny moments of "contamination" by "inferior races and cultures".

Despite the apparent contradiction between theoretical concepts, the present paper aims to prove that positions that are generically defined as Neo-Darwinian were the result not only of the application of evolutionist theories, but also of creationist ones. In the former case, reasoning in which metaphors of conflict and changes in the balance between individuals, "races" or states were preferred, whereas in the latter, rhetoric of preservation or of the reconstruction of "natural hierarchies", resulting from "God's will" was dominant. Both discourses were used (either alternatively or as complements to each other) to consolidate modernist, conservative or traditionalist ideologies.

Contrary to what most authors state, one could say that Portugal also experienced many of the phenomena that took place in other countries, namely the important presence of social Darwinism in Portuguese political and socio-economic thought during the first half of the 20th century. That same influence transpired in the manner in which the historic evolution of the Portuguese elites and popular classes was viewed, as well as in the position taken as to individual features and social inequalities, and finally, in the attitude towards the characteristics and operational rules of international relations.

Amongst other factors, such as the "influence of the geographic environment", the history of Portugal was explained by successive degradation and regeneration processes of the elites' "genetic heritage", associated with a royal family of "superior race” (originating from the South Atlantic region in France). It was described as a succession of positive circumstances, which were glorified, and negative ones, which were forgotten about or hidden. Examples of negative stages included the presence of Jews (and later of "Conversos" or "Marranos"), Muslims, Black slaves and "malignant sets of ideas" because they were "foreign", "contrary to tradition" and/or "contrary to scientific evidence".

In the past as in the future, social inequalities were considered part of the core, unchangeable matrix of "national reality", resulting from the different genetic heritage of every individual (disciplined or undisciplined, honest or dishonest, intellectually able or less able), or of the organic structure of human communities, whose balance and harmony depended on the presence of differing socio-economic functions, as well as a clear and stable hierarchy. These differences were considered to be the result of "God's will" or to be "naturally unavoidable". This trend can clearly be illustrated by the efforts made in terms of the observation and recording of "anthropomorphic indices" of the "lower classes" in general, and more particularly, of the "marginal segments" of the Portuguese population, i.e. criminals, prostitutes, alcoholics and beggars. 
Criteria of "racial order" played a decisive role in the international positioning of Portugal and in colonial relations. Without a shadow of a doubt, Portugal integrated the group of nations responsible for the construction and affirmation of "Western Civilization". However, the "quality of genetic heritage" of the population (or even of the elites) was interpreted differently. At best, the Portuguese were considered a specific type of "superior race", resulting from a mixture of several gene pools (i.e. from Southern and Central/Northern Europe, from pre and post-Roman times, from before and after the "Germanic invasions") and successive adaptations to a particular geographic context. Alternatively, it was considered a community of intermediate "racial quality", inferior to that of the "dominant populations" of Central and Northern Europe but equal or superior to that of all other populations, i.e. Southern Europe and the rest of the world.

Independently of the adopted perspective, both the role of Portugal as a colonising state and the legitimacy of this status were demonstrated by arguments of a historical and cultural nature, such as Portugal's pioneering past and the scale of the country's efforts since the $15^{\text {th }}$ century to "discover new territories and peoples" and introduce millions of human beings to "Western Civilisation". In addition, genetic reasons were used, such as the European character of the "Portuguese race" and "undisputable leadership" of the "Old Continent", or that of "individuals of European origin" on a global scale. The preference for unilateral government modalities, or alternatively, multilateral modalities to govern unipolar, bipolar or multipolar international systems was associated to the "irrefutable truth" of the existence of a permanent struggle between "races" and states for world domination, or on the contrary, for "normal" cooperation between countries aiming to create a binding corps of international law. Portugal would have to choose between a preferential bilateral relation with the hegemonic power in the Atlantic and the membership in international organisations that guaranteed the fundamental rights of small nations.

Most foreign individuals who resided or visited Portugal explicitly interpreted the Portuguese situation and/or disseminated these readings, thus reinforcing the self-perception that we have tried to describe and interpret concisely. The said diplomats, military personnel, entrepreneurs or executives nearly always came from developed countries (especially Britain, France, Belgium, Germany, the USA) and saw the Portuguese as a "mixed race", the fruit of a "superior genetic heritage" mixed with "Mediterranean European", "North African" and "Negroid" traits. This resulted in the proximity of many Portuguese inhabitants to the populations of the colonial territories, protectorates or mandates and to Latin American states; to the unavoidable fact that Lisbon would be under the guardianship of a "Great Power"; to the advantages of the fact that the Government and state apparatus were led by members of the scarce "genetically and intellectually superior" elite - if necessary, by means of dictatorship.

Typically, mass-scale or high levels of violence were not reached. However, during the first half of the $20^{\text {th }}$ century, it is important to note that there were several signs of "systemic Neo-Darwinism". Focusing on the "Metropolis" only, some of the concepts disseminated and options that materialised during the first stages of the Estado Novo (until the end of World War II) were: the Portuguese were divided into "elites", "intermediate groups" and "popular classes", all with differing features and roles; most individuals were considered to have a genetic heritage (i.e. cognitive, moral and 
physiological abilities) compatible with their responsibilities; the global architecture of the "Government system" and sectoral politics (such as education and culture, economics and taxation, "social welfare" and health) should strengthen (and not weaken) the "historic proof" and "scientific evidence" at stake.

Anti-Semitism, which took on several traits, is mentioned as well. In politico-ideological terms, Marxism was seen as a "Jewish world view" and/or part of the "Jewish conspiracy" for world domination. Liberalism, "plutocratic capitalism" and "Masonic agnosticism" were believed to be instruments of "international Judaism". In socio-cultural terms, the Jews were believed to be a non-assimilable race, and Judaism a "false religion". Condemnations of the "excessive presence of Jews" in certain strategic professional fields in other countries received Portuguese support. There was also hostility towards attempts to track down and rebuild "Crypto-Jewish" traditions and "Marrano" communities. On the diplomatic and military levels, the dissemination and agreement with "moderate anti-Semite positions and measures" from other states took place. There was practically no explicit criticism of radical racist ideas and practices, such as the Holocaust.

The present paper concludes by highlighting the scientific values of a more in-depth study of the presence of social Darwinian readings in Portugal, and of their influence on a wide range of world views and activities. Issues such as the importance of Neo-Darwinism in Portugal during the first half of the $20^{\text {th }}$ century have been sufficiently discussed, as well as the central position of this form of scientism (rationalist or irrationalist, modernising, conservative or traditionalist) in multiple sectors of Portuguese life, and the similarities between Portuguese social Darwinism and its evolution both in most European countries and in other states of the world.

\section{Documentation and bibliography}

ALEXANDrE, Valentim, Velho Brasil, novas Áricas. Portugal e o Império (1808-1975), Porto, Edições Afrontamento, 2000.

AMEAL, João, História de Portugal, Porto, Livraria Tavares Martins, 1940.

BRAUDEL, Fernand, Gramática das civilizaçôes (translation from French), Lisboa, Editorial Teorema, 1989.

CEREJEIRA, Manuel Gonçalves, Obras pastorais, 7 volumes, Lisboa, União Gráfica, 1936-1970.

Congresso Nacional das Ciências da População. Actas, memórias e comunicaçōes, Lisboa, Comissão Executiva dos Centenários, 1940, vols. XVII e XVIII.

I Congresso da União Nacional. Discursos, teses e comunicações, 8 volumes, Lisboa, UN, 1935.

DURAND, Yves, Le nouvel ordre européen nazi (1938-1945), Bruxelles, Éditions Complexe, 1990.

FERRO, António, Salazar. O homem e a sua obra, Lisboa, ENP, 1933.

GEARY, Patrick J., O mito das Nações. A invenção do nacionalismo (translation from English), Lisboa, Gradiva, 2008.

HAWKINS, Mike, Social Darwinism in European and American thought (1860-1945), Cambridge, CUP, 1998. Indústria Portuguesa [no 1, March of 1928 - no 250, Dezember of 1948].

JOLL, James, A Europa desde 1870 (translation from English), Lisboa, Publicações Dom Quixote, 1982.

LEAL, João, Antropologia em Portugal, Lisboa, Livros Horizonte, 2006. 
LIMA, Joaquim Alberto Pires de, Mouros, judeus e negros na história de Portugal, Porto, Livraria Civilização, 1940.

LOFF, Manuel, As duas ditaduras ibéricas na nova ordem eurofascista (1936-1945), Florença, 2004, vol. 3 (multicopied).

Lumen [fasc. 1, January of 1937 - fasc. 12, December of 1947].

MEA, Elvira de Azevedo e STEINHARDT, Inácio, Ben-Rosh. Biografia do Capitão Barros Basto, o apóstolo dos Marranos, Porto, Ediçôes Afrontamento, 1997.

MILZA, Pierre, As relações internacionais de 1918 a 1939 (translation from French), Lisboa, Edições 70, 1998.

NUNES, João Paulo Avelãs e outros, O CADC de Coimbra, a democracia cristã e os inícios do Estado Novo (1905-1934), Coimbra, FLUC, 1993.

NUNES, João Paulo Avelãs, A história económica e social na FLUC (1911-1974), Lisboa, IIE, 1995.

NUNES, João Paulo Avelãs, O Estado Novo e o volfrâmio (1933-1947), 2 volumes, Coimbra, 2005 (multicopied).

PEREIRA, Ana Leonor, Darwin em Portugal: filosofia, história, engenharia social (1865-1914), Coimbra, Livraria Almedina, 2001.

RÉMOND, René, Introdução à história do nosso tempo (translation from French), Lisboa, Gradiva, 1994.

SALAZAR, António de Oliveira, Discursos e notas politicas, 6 volumes, Coimbra, Coimbra Editora, 1945-1967.

SEN, Amartya, Identidade e violência. A ilusão do destino (translation from French), Lisboa, Ediçôes Tinta-da-China, 2007.

SÉRGIO, António, Bosquejo da história de Portugal, Lisboa, Publicações da Biblioteca Nacional, 1923.

STERNHELL, Zeev, La droite révolutionnaire (1885-1914). Les origines françaises du fascisme, Paris, Éditions du Seuil, 1978.

TELO, António José e TORRE GÓMEZ, Hipólito de la, Portugal e a Espanha nos istemas internacionais contemporâneos, Lisboa, Edições Cosmos, 2000.

WINOCK, Michel, Nationalisme, antisémitisme et fascisme en France, Paris, Éditions du Seuil, 1982. 